\title{
39. INTERSTITIAL-WATER CHEMISTRY: ABYSSAL SOUTH ATLANTIC AND EAST GEORGIA BASINS, ISLAS ORCADAS AND METEOR RISES ${ }^{1}$
}

\author{
P. N. Froelich, ${ }^{2}$ R. A. Mortlock, ${ }^{2}$ M. Mefferd,${ }^{3}$ and J. Powers ${ }^{3}$
}

\begin{abstract}
Pore-water samples were recovered at five sites from ODP Leg 114 in the subantarctic South Atlantic Ocean and analyzed for $\mathrm{pH}$, alkalinity, chloride, sulfate, fluoride, silica, magnesium, calcium, strontium, potassium, lithium, and barium. At sites in the East Georgia Basin and on the Islas Orcadas Rise, Ca increases and $\mathrm{Mg}$ decreases linearly downhole with a $\Delta \mathrm{Mg} / \Delta \mathrm{Ca}$ ratio reflecting conservative diffusive exchange and basalt basement reactions. At sites on the west flank of the Mid-Atlantic Ridge and on the Meteor Rise, Ca gradients are nonlinear, and nonconservative $\Delta \mathrm{Mg} / \Delta \mathrm{Ca}$ ratios reflect alteration reactions of abundant silicic volcanic ash in the sediment. $\mathrm{K}$ decreases linearly downhole at all sites, reflecting uptake by basement and the absence of significant sediment-hosted reactions. $\mathrm{SO}_{4}$ decreases and alkalinity increases downhole are due to a slight sulfate reduction at all sites except at $\mathrm{Site} 701$. $\mathrm{Sr}$ increases downhole at all sites except Site 701 , with $\Delta \mathrm{Sr} / \Delta \mathrm{Ca}$ ratios reflecting diffusive exchange with basement. At Site 704 on the Meteor Rise, there is intense Sr production during carbonate recrystallization in the upper 200 mbsf. Below 200 mbsf at Site 704, the ion concentration product of $\mathrm{SrSO}_{4}$ is constant, suggesting $\mathrm{Sr}$ control by celestite solubility. $\mathrm{Li}$ and $\mathrm{F}$ concentrations display complex behavior related to sedimentary reactions, probably calcite recrystallization ( $\mathrm{Li}$ uptake and $\mathrm{F}$ release).
\end{abstract}

\section{INTRODUCTION}

Ocean Drilling Program (ODP) Leg 114 consisted of a longitudinal transect across $50^{\circ} \mathrm{S}$ in the subantarctic South Atlantic between latitudes of $31^{\circ} \mathrm{W}$ and $8^{\circ} \mathrm{E}$. Sites were occupied in the East Georgia Basin, the abyssal South Atlantic Ocean (western flank of the Mid-Atlantic Ridge), and atop the Islas Orcadas and Meteor rises (Table 1). The major objectives of this leg were to recover continuous Neogene and Paleogene sections to reconstruct the paleoceanography of the South Atlantic during the initiation of Antarctic glaciation and to monitor the development and northward migration of the global circumpolar Antarctic circulation and deep- and bottom-water flow paths as oceanic gateways opened among Africa, South America, and Antarctica. Recovered sections range in age from Late Cretaceous through Quaternary with a lithology encompassing siliceous and calcareous oozes, chalks, limestones (no dolomite), volcanic ashes, zeolites, cherts, and basement (Table 1). As such, these sections represent a wide variety of lithology within which to investigate reactions controlling the behavior of pore-water constituents. Our particular interest in this leg arose from the possibility of recovering complete high-latitude Neogene biosiliceous sections in which to study late Oligocene through Quaternary biogenic opal production, dissolution, preservation, and diagenesis and to reconstruct a high-resolution record of $(\mathrm{Ge} / \mathrm{Si})_{\text {opal }}$ variations in sediments that had been well studied geochemically (Shemesh et al., 1989; Froelich et al., 1989). The results of this latter work are not complete at this writing and will be presented with a discussion of silica diagenesis elsewhere.

\footnotetext{
${ }^{1}$ Ciesielski, P. F., Kristoffersen, Y., et al., 1991. Proc. ODP, Sci, Results, 114: College Station, TX (Ocean Drilling Program).

2 Lamont-Doherty Geological Observatory, Columbia University, Palisades, NY 10964.

${ }^{3}$ Ocean Drilling Program, Texas A\&M University, 1000 Discovery Drive, College Station, TX 77845-9547.
}

\section{METHODS}

All pore waters were expressed with stainless-steel squeezers in hydraulic presses from $5-$ or $10-\mathrm{cm}$ whole-round samples cut from the cores immediately after retrieval (Manheim and Sayles, 1974). For Sites 699, 700, and 701, pore fluids were expressed at ambient temperatures directly into precleaned polyethylene syringes, and then post-filtered through $0.4-\mu \mathrm{m}$ membrane filters into precleaned polyethylene vials (for shipboard determinations) and bottles (for transport to the laboratory). For Sites 702 and 704, the squeezers were maintained at bottom-water temperatures in a refrigerator $\left(2^{\circ}-4^{\circ} \mathrm{C}\right)$ prior to loading sediment in an attempt to eliminate temperature-of-extraction artifacts for $\mathrm{F}, \mathrm{Li}, \mathrm{Ba}$, and $\mathrm{Si}$. For these two sites, pore waters were expressed into a syringe through a $0.4-\mu \mathrm{m}$ membrane filter held in a syringe filter holder that was inserted directly into the squeezer port. The contents of the syringes were again post-filtered into vials and bottles. The temperature of the effluent fluid increased less than $2^{\circ} \mathrm{C}$ during pore-water extraction, indicating that the squeezers have sufficient thermal inertia to maintain the initial temperature over the $10-20 \mathrm{~min}$ required for squeezing the high-porosity, poorly consolidated sediments of these holes.

Values of $\mathrm{pH}$, alkalinity, salinity, chloride, calcium, magnesium, and sulfate were determined aboard ship using standard ODP methods (Table 2). The $\mathrm{pH}$, alkalinity, and salinity were measured immediately after pore-water extraction, and chloride, calcium, magnesium, and sulfate were generally run within $24 \mathrm{hr}$ of collection. Silica was determined aboard ship within four days with a technique modified from Mortlock and Froelich (1989). Fluoride was determined immediately aboard ship by fluoride specific-ion combination electrode using the method of Froelich et al. (1983). The methods of analyses and calibrations for all shipboard determinations are described in detail in the "Explanatory Notes" (Shipboard Scientific Party, 1988).

Potassium, strontium, lithium, and barium were determined in the shorebased laboratory at Lamont-Doherty Geological Observatory from splits (unacidified) of the same samples ana- 
Table 1. Pore-water sampling sites, Leg 114.

\begin{tabular}{|c|c|c|c|c|c|}
\hline Site & Location & Age & Lithology & $\begin{array}{l}\text { Water } \\
\text { depth } \\
\text { (m) }\end{array}$ & $\begin{array}{c}\text { Temperature }{ }^{\mathrm{a}} \\
\left({ }^{\circ} \mathrm{C}\right)\end{array}$ \\
\hline 699 & $\begin{array}{l}\text { East Georgia Basin } \\
51^{\circ} 32.537^{\prime} \mathrm{S} \text {, } \\
30^{\circ} 40.619^{\prime} \mathrm{W}\end{array}$ & $\begin{array}{l}\text { early Eocene } \\
\text { to early } \\
\text { Miocene }\end{array}$ & $\begin{array}{l}\text { Diatomaceous clay, siliceous } \\
\text { nannofossil ooze-chalk-micrite, } \\
\text { with zeolitic clay near } \\
\text { basement }\end{array}$ & 3706 & 22 \\
\hline 700 & $\begin{array}{l}\text { East Georgia Basin } \\
51^{\circ} 31.992^{\prime} \mathrm{S} \text {, } \\
30^{\circ} 16.697^{\prime} \mathrm{W}\end{array}$ & $\begin{array}{l}\text { early } \\
\text { Campanian to } \\
\text { late middle } \\
\text { Eocene }\end{array}$ & $\begin{array}{l}\text { Nannofossil } \\
\text { ooze-chalk-micrite-limestone }\end{array}$ & 3601 & 22 \\
\hline 701 & $\begin{array}{l}\text { West flank of } \\
\text { Mid-Atlantic Ridge } \\
51^{\circ} 59.07^{\prime} \mathrm{S} \text {, } \\
23^{\circ} 12.73^{\prime} \mathrm{W}\end{array}$ & $\begin{array}{l}\text { early Eocene } \\
\text { to } \\
\text { Quaternary }\end{array}$ & $\begin{array}{l}\text { Diatomaceous ooze, with ash, } \\
\text { nannofossil ooze-chalk, basal } \\
\text { zeolites overlying mid-ocean } \\
\text { ridge basalt }\end{array}$ & 4627 & 22 \\
\hline 702 & $\begin{array}{l}\text { Islas Orcadas Rise } \\
50^{\circ} 56.786^{\prime} \mathrm{S} \text {, } \\
26^{\circ} 22.117^{\prime} \mathrm{W}\end{array}$ & $\begin{array}{l}\text { late } \\
\text { Paleocene to } \\
\text { late Miocene }\end{array}$ & $\begin{array}{l}\text { Nannofossil-diatom } \\
\text { ooze-chalk, trace ash + chert } \\
\text { stringers, basal silicified } \\
\text { limestone + zeolites }\end{array}$ & 3083 & 4 \\
\hline 704 & $\begin{array}{l}\text { Southern Meteor Rise } \\
46^{\circ} 52.757^{\prime} \mathrm{S} \text {, } \\
07^{\circ} 25.250^{\prime} \mathrm{E}\end{array}$ & $\begin{array}{l}\text { middle } \\
\text { Oligocene to } \\
\text { Quaternary }\end{array}$ & $\begin{array}{l}\text { Diatom-calcareous ooze, } \\
\text { micritic nannofossil chalk, } \\
\text { with dispersed volcanic ash }\end{array}$ & 2532 & 4 \\
\hline
\end{tabular}

${ }^{a}$ At which pore waters were extracted (see text).

lyzed aboard ship (Table 2). These samples were maintained at $4^{\circ} \mathrm{C}$ in a humidified core-storage locker for longer than $1 \mathrm{yr}$ before being analyzed. Potassium was determined by flame emission with a Perkin Elmer 5000 Atomic Absorption Spectrometer. Samples and standards were diluted by a factor of 200 with a $20-\mathrm{mM} \mathrm{NaCl}$ solution. Strontium and lithium were determined by flame atomic absorption spectrometry. For strontium, samples and standards were diluted by a factor of 20 with a $0.1 \%$ lanthanum solution and determinations were by standard additions of Sr. For lithium, samples were diluted 1:1 with distilled-deionized water (DDW), and standards (in a DDW matrix) were diluted $1: 1$ with a $500-\mathrm{mM} \mathrm{NaCl}$ solution. Barium was determined by graphite-furnace atomic absorption spectrometry using Zeeman background correction. Samples and standards were diluted to the range of $0-250-\mathrm{nM}$ Ba with DDW. Strontium isotopes and inorganic germanium are also being determined on these samples, the results of which will be reported elsewhere.

\section{RESULTS}

The pore-water data from all sites are presented in Table 3 and plotted vs. sub-bottom depth in Figure 1. The water depth, lithology, and age of each site are summarized in Table 1. In general, the pore-water profiles at these sites can be related to several processes (Gieskes, 1981): (1) downward diffusion of late Pleistocene oceanic salinity variations imparted by the waxing and waning of continental glacial ice (salinity and chloride); (2) diffusion through the sediment column between the overlying water column and basement reactions involving low-temperature basalt-seawater interactions ( $\mathrm{Ca}, \mathrm{Mg}, \mathrm{K}, \mathrm{Sr}$, and $\mathrm{Li}$ ); (3) sedimentary silicic volcanic ash alteration reactions $(\mathrm{Ca}, \mathrm{Mg}$, and $\mathrm{Li})$; (4) sedimentary calcite recrystallization reactions ( $\mathrm{Sr}, \mathrm{F}$, and $\mathrm{Li}$ ); and (5) silica diagenesis ( $\mathrm{Si})$. In the following discussions, we will briefly consider the effects of the first four of these processes on the pore-water profiles at Leg 114 sites.

\section{DISCUSSION}

\section{Salinity Variations}

Downhole salinity and chloride variations at these sites are likely caused by variations in bottom-water salinity during the
Table 2. Pore-water analytical methods.

\begin{tabular}{|c|c|c|}
\hline Analyte & Method & Reference \\
\hline $\mathrm{pH}$ & Glass electrode & Gieskes and Peretsman (1986) \\
\hline Alkalinity & $\begin{array}{l}\text { Potentiometric Gran } \\
\text { titration }\end{array}$ & Gieskes and Peretsman (1986) \\
\hline Salinity & Refractometer & \\
\hline & Colorimetric titration & Gieskes and Peretsman (1986) \\
\hline $\mathrm{Ca}$ & Colorimetric titration & Gieskes and Peretsman (1986) \\
\hline $\mathrm{Cl}$ & Colorimetric titration & Gieskes and Peretsman (1986) \\
\hline $\mathrm{SO}_{4}$ & Ion chromatography & Gieskes and Peretsman (1986) \\
\hline$F$ & Specific ion electrode & Froelich et al. (1983) \\
\hline $\mathrm{Si}$ & $\begin{array}{l}\text { Molybdate-blue } \\
\text { spectrophotometry }\end{array}$ & Mortlock and Froelich (1989) \\
\hline $\mathrm{Sr}$ & $\begin{array}{l}\text { Flame atomic absorption } \\
\text { spectrometry }\end{array}$ & Gieskes (1974) \\
\hline $\mathrm{K}$ & Flame emission & Gieskes (1974) \\
\hline $\mathrm{Li}$ & $\begin{array}{l}\text { Flame atomic absorption } \\
\text { spectrometry }\end{array}$ & von Damm (1983) \\
\hline Ba & $\begin{array}{l}\text { Graphite-furnace atomic } \\
\text { absorption spectrometry } \\
\text { with Zeeman correction }\end{array}$ & Bishop (1990) \\
\hline
\end{tabular}

late Pleistocene (McDuff, 1985). Changes in the salinity of the overlying water impart diffusion gradients downward into the sediment column, the amplitude of which is damped with increasing depth. Thus the "ages" of such variations increase exponentially with increasing sub-bottom depth and are not linked to stratigraphic age. These changes have been previously linked to whole-ocean changes in salinity caused by the waxing and waning of the continental ice sheets. While this is undoubtedly the major global cause behind these observations, we suggest here that local water mass variations may also be involved. Paleoceanographic inferences can thus be drawn from differences in the chloride profiles at our sites. Sites 699 and 702 (both in the western Atlantic) and 704 (in the eastern Atlantic) display chloride profiles with near-surface minima (low Holocene-ocean salinities) and sub-bottom maxima at 20 to $50 \mathrm{~m}$ below seafloor (mbsf) (higher glacial-ocean salinities), below which chloride concentrations slowly decrease (pre-Pleistocene low-salinity ocean) (Fig. 2). The shapes of these profiles are fairly typical of "normal" pelagic sites (McDuff, 1985). These three sites are at mid-water depths 
$(2500-3700 \mathrm{~m})$ under the influence today of Circum-Polar Deep Water (CPDW), with Site 704 being more influenced by high-salinity North Atlantic Deep Water (NADW). The time scale for diffusion to sub-bottom depths of 20 to $50 \mathrm{mbsf}$ is 100,000 to $700,000 \mathrm{yr}$, suggesting that average deep-water salinities were higher at these three sites over this period of intense late Pleistocene glaciation. The magnitude of the increase is both greater and of longer duration than at Site 704, suggesting that the upper deep water in the eastern South Atlantic Ocean was more influenced by NADW than in the western basin. In addition, the salinities of Sites 699,702 , and 704 converge on the same values below 150 mbsf. The time scale for diffusion to $150 \mathrm{mbsf}$ is about $6,000,000 \mathrm{yr}$, suggesting that these three sites experienced the same salinities prior to the late Miocene.

In contrast, Site 701 is in a water depth of $4600 \mathrm{~m}$, positioned within the main pathway of northward Antarctic Bottom Water (AABW) flow from the Weddell Sea into the Argentine Basin. This bottom-water site is remarkable in two important respects: (1) the absence of significant salinity (chloride) variations downhole and (2) salinities (chlorides) that are always lower than at the shallower sites for depths greater than $10 \mathrm{mbsf}$. Apparently, bottom-water salinities over Site 701 have not varied significantly over the last several million years. This suggests that AABW flow northward has been continuous over the last several million years and has not varied greatly in salinity.

\section{Basalt Basement Reactions vs. Silicic Volcanic Ash Alteration}

Concentrations of calcium increase and those of magnesium and potassium decrease downhole at all sites. Potassium decreases are fairly linear at all sites, suggesting the absence of significant sedimentary reactions and control by low-temperature $\mathrm{K}$ uptake into basement.

At Sites 699, 700, and 702, the downhole gradients in $\mathrm{Ca}$ and $\mathrm{Mg}$ are linear with depth and reflect diffusional gradients between the overlying seawater and basalt-seawater reactions occurring in basement (McDuff, 1981; Gieskes, 1983; Gieskes et al., 1984). The calcium vs. magnesium relationship at these three sites is linear with a $\Delta \mathrm{Mg} / \Delta \mathrm{Ca}$ slope of -0.5 (Fig. 3B), a typical "conservative" profile diagnostic of basalt basement reactions (Baker, 1986). Thus, the pore-water data are consistent with the interpretation that basements of the East Georgia Basin and the Islas Orcadas Rise are composed of basalt and with the observed absence of either dolomite or volcanic ash within the sediment at these three sites.

Sites 701 and 704 , on the other hand, while displaying linear downward $\mathrm{K}$ gradients, show nonconservative $\mathrm{Ca}$ and $\mathrm{Mg}$ gradients resulting from alteration reactions of silicic volcanic ash throughout the upper part of the section (Gieskes and Lawrence, 1981; Gieskes, 1983; Baker, 1986). Sedimentary ash reactions apparently dominate the $\mathrm{Ca}$ and $\mathrm{Mg}$ profiles so that diffusive exchange between seawater and the underlying basaltic basement reactions do not control the $\mathrm{Mg} / \mathrm{Ca}$ ratio. The vertical profiles of $\mathrm{Ca}$ and $\mathrm{Mg}$ at Sites 701 and 704 are thus nonlinear, and the $\mathrm{Ca}$ vs. $\mathrm{Mg}$ trend is also nonlinear but approaches a slope of -2.0 (Fig. 3B), which is characteristic of reactions with silicic minerals (Baker, 1986). This is again consistent with the observation of abundant ash horizons at Site 701 and dispersed ash within the upper $50 \mathrm{~m}$ at Site 704 . Sites 701 and 704 are farther east than the other sites of Leg 114 and presumably received ash falls from explosive volcanic eruptions in the Scotia Arc, which is $510 \mathrm{~km}$ southwest and upwind of Site 701.
Pore-water lithium profiles at Sites 699,700 , and 702 display approximately linear downward-increasing gradients that parallel the calcium gradients, suggesting diffusive exchange with basement reactions (Fig. 1). The profile at Site 701 shows a maximum at about 300 mbsf, with apparent production of $\mathrm{Li}$ throughout the sediment column between about 300 and $450 \mathrm{mbsf}$. This behavior may be linked to the alteration of abundant silicic volcanic ash. At Site 704, on the other hand, the lithium profile displays a dramatic minimum at 200-300 mbsf, requiring $\mathrm{Li}$ consumption reactions within this interval. A plot of $\mathrm{Li}$ vs. $\mathrm{K}$ for these sites (Fig. $3 \mathrm{C}$ ) demonstrates the lack of any simple relationship, although it is clear that the sites in the East Georgia Basin (Sites 699 and 700) and on the outer flank of the Mid-Atlantic Ridge (Site 701) display higher $\mathrm{Li} / \mathrm{K}$ gradients than the two sites atop the conjugate Islas Orcadas (Site 702) and Meteor (Site 704) rises. A plot of $\mathrm{Li} / \mathrm{Ca}$ (normalized for basement exchange) vs. fluoride (Fig. 3D) suggests that fluoride and lithium behave inversely during sediment diagenesis, a point that will be discussed further in the following text.

\section{Sedimentary Calcite Recrystallization}

The most sensitive indicator of calcite dissolution is strontium. In the Leg 114 sites, $\mathrm{Sr}$ displays three distinct styles of behavior: (1) unreactive (Site 701), (2) diffusive exchange with basement (Sites 699, 700, and 702), and (3) carbonate recrystallization (Site 704). Site 701, the deepest of our sites, displays $\mathrm{Sr}$ concentrations only slightly elevated above bottom-water concentrations $(90 \mu \mathrm{M})$. Thus we infer that there are no contemporaneous calcite recrystallization reactions occurring in the sediment column at Site 701, where the sediments are devoid of carbonate, and that $\mathrm{Sr}$ release from basement reactions is small. In contrast, at Sites 699,700 , and $702, \mathrm{Sr}$ increases rapidly and linearly downhole, with a constant $\Delta \mathrm{Sr} / \Delta \mathrm{Ca}$ slope of about $36 \times 10^{-3}$ (Fig. 3A). We infer that this behavior reflects diffusive exchange with reactions releasing $\mathrm{Sr}$ from below the recovered interval, perhaps basal carbonate recrystallization reactions.

Site 704 displays dramatically different behavior. Here Sr increases rapidly in the upper $200 \mathrm{~m}$ to over $1000 \mu \mathrm{M}$, and then plateaus with concentrations increasing more slowly in the bottom $500 \mathrm{~m}$. The $\Delta \mathrm{Sr} / \Delta \mathrm{Ca}$ slope in the upper part of the section is about $220 \times 10^{-3}$, indicative of $\mathrm{Sr}$ exclusion from biogenic carbonates (possibly including aragonite) upon recrystallization to calcite. At high concentrations, $\mathrm{Sr}$ may be controlled by celestite $\left(\mathrm{SrSO}_{4}\right)$ solubility (Baker, 1986). A plot of $\mathrm{Sr}$ vs. $\mathrm{SO}_{4}$ (Fig. 4A) demonstrates an indirect relationship between $\mathrm{Sr}$ and $\mathrm{SO}_{4}$ at all sites except Site 701, reflecting downward-decreasing sulfate and -increasing strontium suggestive of celestite solubility control. However, a plot of the ion concentration product of celestite (ICP) vs. sub-bottom depth for all sites (Fig. 4B) demonstrates that near-constant values of the ICP are reached only below 200 mbsf at Site 704 and near the bottoms of Sites 699 and 702 . The higher apparent solubility product for celestite at Site 704 on the Meteor Rise $\left(\mathrm{ICP}=21 \times 10^{-3}\right)$ compared to the Lord Howe Rise sites (ICP $=15 \times 10^{-3}$; Baker, 1986) may be related to the greater water depth for the Meteor Rise site and thus an increase in the solubility product at greater pressures (Baker and Bloomer, 1988). No celestite nodules were observed at Site 704 .

Fluoride is released during calcite dissolution and recrystallization reactions. At Site 704, fluoride increases dramatically downhole to a maximum concentration about four times that of seawater by $300 \mathrm{mbsf}$. Biogenic carbonates 
Table 3. Leg 114 pore-water data.

\begin{tabular}{|c|c|c|c|c|c|c|c|c|c|c|c|c|c|c|}
\hline $\begin{array}{l}\text { Core, section, } \\
\text { interval }(\mathrm{cm})\end{array}$ & $\begin{array}{l}\text { Depth } \\
\text { (mbsf) }\end{array}$ & $\mathrm{pH}$ & $\begin{array}{l}\text { Alkalinity } \\
(\mathrm{mM})\end{array}$ & $\begin{array}{l}\text { Salinity } \\
(\% / \%)\end{array}$ & $\underset{(\mathrm{mM})}{\mathrm{Mg}}$ & $\underset{(\mathrm{mM})}{\mathrm{Ca}}$ & $\underset{(\mathrm{mM})}{\mathrm{Cl}}$ & $\underset{(\mathrm{mM})}{\mathrm{SO}_{4}}$ & $\underset{(\mu \mathrm{M})}{\mathrm{F}}$ & $\underset{(\mu \mathrm{M})}{\mathrm{Si}}$ & $\underset{(\mu \mathrm{M})}{\mathrm{Sr}}$ & $\underset{(\mathrm{mM})}{\mathrm{K}}$ & $\underset{(\mu \mathrm{M})}{\mathrm{Li}}$ & $\underset{(\mathrm{nM})}{\mathrm{Ba}}$ \\
\hline \multicolumn{15}{|l|}{ 114-699A- } \\
\hline $1 \mathrm{H}-4,145-150$ & 5.9 & 7.73 & 3.09 & 34.2 & 51.48 & 10.88 & 554.1 & 28.30 & 62.2 & 822 & 127 & 10.66 & 26.0 & 693 \\
\hline $3 \mathrm{H}-3,145-150$ & 22.5 & 7.46 & 3.45 & 35.4 & 51.24 & 12.49 & 569.9 & 27.90 & 41.1 & 730 & 140 & 10.31 & 26.0 & 593 \\
\hline $6 \mathrm{H}-5,145-150$ & 54.0 & 7.83 & 4.08 & 35.0 & 48.89 & 14.60 & 568.9 & 26.80 & 41.4 & 872 & 197 & 10.40 & 42.8 & 640 \\
\hline $9 \mathrm{H}-4,145-150$ & 81.0 & 7.78 & 4.50 & 35.0 & 47.85 & 16.12 & 565.9 & 26.30 & 41.9 & 984 & 230 & 10.79 & 57.8 & 495 \\
\hline $12 \mathrm{H}-4,145-150$ & 109.5 & 7.76 & 4.51 & 35.0 & 47.47 & 18.04 & 566.9 & 25.10 & 36.0 & 950 & 257 & 10.22 & 73.6 & 392 \\
\hline $15 \mathrm{H}-3,145-150$ & 136.5 & 7.46 & 4.79 & 35.0 & 45.80 & 19.63 & 560.0 & 25.10 & 30.9 & 997 & 303 & 10.00 & 83.5 & 505 \\
\hline $18 \mathrm{H}-4,145-150$ & 166.5 & 7.22 & 4.54 & 34.8 & 44.73 & 20.85 & 561.0 & 24.80 & 28.5 & 1152 & 341 & 9.39 & 96.6 & 483 \\
\hline $21 \mathrm{H}-4,140-150$ & 195.0 & 7.24 & 4.71 & 34.8 & 43.37 & 22.85 & 565.9 & 24.30 & 25.9 & 1090 & 383 & 9.39 & 108.0 & 451 \\
\hline $24 X-2,140-150$ & 217.5 & 8.14 & 4.94 & 34.8 & 43.74 & 22.84 & 567.9 & 24.40 & 22.2 & 1073 & 408 & 8.42 & 110.0 & 688 \\
\hline $30 X-3,140-150$ & 273.0 & 7.25 & 5.60 & 35.0 & 40.59 & 26.67 & 568.9 & 23.90 & 19.0 & 1094 & 479 & 8.33 & 135.0 & 446 \\
\hline $33 X-5,140-150$ & 304.5 & 7.23 & 5.23 & 35.0 & 40.75 & 26.75 & 570.0 & 23.60 & 19.4 & 1032 & 490 & 8.38 & 135.0 & 550 \\
\hline $36 X-5,140-150$ & 333.0 & 7.25 & 4.98 & 34.8 & 38.81 & 28.85 & 569.9 & 23.60 & 17.5 & 1146 & 488 & 7.02 & 145.0 & 2058 \\
\hline $39 X-1,140-150$ & 355.5 & (7.85) & $(4.79)$ & $(34.0)$ & $(41.18)$ & (33.58) & $(536.2)$ & $(21.00)$ & (16.3) & $(655)$ & & & & \\
\hline $42 X-5,140-150$ & 390.0 & & & (33.7) & $(39.51)$ & (36.27) & $(539.2)$ & $(20.30)$ & (19.3) & (595) & (711) & $(4.65)$ & $(194.0)$ & (1320) \\
\hline $45 X-5,140-150$ & 418.5 & & & 33.8 & 37.02 & 35.36 & 559.0 & 22.10 & 26.1 & 508 & 915 & & & \\
\hline $48 X-4,140-150$ & 445.5 & 7.19 & 3.56 & & & & 555.0 & 25.20 & 34.5 & 408 & 556 & 7.31 & 115.0 & 2736 \\
\hline $48 X-4,140-150$ & 445.5 & $(7.43)$ & $(3.71)$ & (33.8) & & & (551.1) & & (33.8) & $(484)$ & (563) & (7.24) & (128.0) & (1127) \\
\hline $54 X-1,140-150$ & 498.0 & & & 32.3 & 33.60 & 38.62 & 531.2 & 19.40 & 30.2 & 577 & 1018 & & & \\
\hline \multicolumn{15}{|l|}{$114 \mathrm{~B}-700 \mathrm{~B}-$} \\
\hline $3 R-1,145-150$ & 27.8 & 7.76 & 3.70 & 34.6 & 51.57 & 12.02 & 553.2 & 26.72 & 76.1 & 761 & 150 & 10.88 & 35.7 & 1895 \\
\hline $6 \mathrm{R}-5,145-150$ & 62.3 & 7.55 & 4.01 & 34.8 & 48.91 & 14.52 & 548.3 & 25.32 & 60.2 & 418 & 218 & 10.44 & 42.0 & 759 \\
\hline $9 \mathrm{R}-5,145-150$ & 90.8 & 7.20 & 4.06 & 35.2 & 48.07 & 17.02 & 555.1 & 24.74 & 58.3 & 379 & 331 & 10.44 & 49.5 & 530 \\
\hline $13 \mathrm{R}-4,140-150$ & 127.3 & 7.55 & 3.95 & 35.0 & 46.28 & 19.37 & 556.1 & 25.16 & 58.7 & 605 & 369 & 9.39 & 52.0 & 1642 \\
\hline $16 \mathrm{R}-5,140-150$ & 157.3 & 7.35 & 5.12 & 35.2 & 44.50 & 22.96 & 561.9 & 23.98 & 60.6 & 465 & 467 & 8.90 & 60.1 & 1014 \\
\hline $20 \mathrm{R}-2,140-150$ & 190.8 & 7.63 & 4.35 & 35.0 & 43.50 & 23.49 & 555.1 & 24.04 & 61.9 & 569 & 501 & 9.65 & 62.7 & 1146 \\
\hline $26 \mathrm{R}-2,140-150$ & 240.9 & 7.45 & 4.26 & 35.0 & 39.98 & 28.51 & 549.3 & 22.82 & 54.2 & 1131 & 628 & 7.41 & 75.2 & 2766 \\
\hline \multicolumn{15}{|l|}{ 114-701A- } \\
\hline $1 \mathrm{H}-4,145-150$ & 5.9 & 7.69 & 4.21 & 34.8 & 52.67 & 10.99 & 558.0 & 27.30 & 61.6 & 811 & 97 & 9.83 & 24.4 & 644 \\
\hline $3 \mathrm{H}-4,145-150$ & 23.7 & 7.73 & 5.00 & 35.0 & 52.32 & 11.35 & 557.0 & 26.80 & 43.6 & 950 & 98 & 10.09 & 24.4 & 1029 \\
\hline $6 \mathrm{H}-5,145-150$ & 53.7 & 7.69 & 5.66 & 35.0 & 50.59 & 12.13 & 558.0 & 25.40 & 33.9 & 861 & 119 & 9.83 & 30.1 & 544 \\
\hline \multicolumn{15}{|l|}{ 114-701B- } \\
\hline $1 \mathrm{H}-5,145-150$ & 77.4 & 7.62 & 6.03 & 34.8 & 49.51 & 12.13 & 554.0 & 24.50 & 30.9 & 969 & 119 & 10.53 & 35.7 & 699 \\
\hline $4 \mathrm{H}-5,145-150$ & 105.9 & 7.59 & 6.19 & 34.6 & 47.95 & 12.87 & 555.0 & 24.40 & 27.7 & 979 & 127 & 10.09 & 42.6 & 536 \\
\hline $7 \mathrm{H}-4,145-150$ & 132.9 & 7.58 & 6.33 & 34.2 & 46.50 & 13.29 & 553.0 & 24.10 & 25.6 & 1044 & 122 & 10.00 & 47.0 & 585 \\
\hline $9 \mathrm{H}-5,46-50$ & 150.0 & 7.72 & 5.95 & 34.5 & 46.62 & 13.49 & 558.0 & 24.50 & 30.5 & 1320 & 129 & 10.62 & 52.0 & 1058 \\
\hline $13 \mathrm{H}-3,140-150$ & 188.4 & 7.51 & 6.60 & 34.3 & 45.95 & 14.02 & 557.0 & 23.00 & 28.2 & 1080 & 136 & 9.65 & 59.5 & 489 \\
\hline $114-701 C$ - & 155.7 & 7.74 & 6.47 & 34.6 & 46.62 & 13.67 & 553.0 & 24.09 & 24.2 & 1171 & 133 & 9.65 & 52.6 & 613 \\
\hline $23 \mathrm{H}-4,140-150$ & 211.7 & 7.82 & 6.67 & 34.2 & 45.95 & 14.18 & 551.0 & 23.65 & 25.1 & 1063 & 117 & 10.18 & 61.4 & 46 \\
\hline $27 \mathrm{H}-2,140-150$ & 246.7 & 7.77 & 6.27 & 34.0 & 45.09 & 14.33 & 549.0 & 21.14 & 27.7 & 1184 & 137 & 9.08 & 65.8 & 720 \\
\hline $31 X-2,140-150$ & 284.7 & 7.68 & 6.05 & 34.5 & 45.32 & 14.65 & 550.0 & 23.45 & 27.7 & 962 & 137 & 8.99 & 65.8 & 492 \\
\hline $34 X-4,140-150$ & 316.2 & 7.89 & 6.28 & 34.4 & 43.64 & 15.03 & 550.0 & 23.90 & 26.2 & 1028 & 128 & 9.34 & 67.0 & 496 \\
\hline $37 X-3,140-150$ & 343.2 & 7.65 & 6.33 & 34.0 & 43.71 & 15.26 & 546.0 & 24.17 & 27.7 & 1083 & 130 & 9.34 & 65.8 & 490 \\
\hline $42 X-1,140-150$ & 387.7 & 7.61 & 6.11 & 33.8 & 49.53 & 16.27 & 543.0 & 23.40 & 29.8 & 1192 & & & & \\
\hline $45 X-4,140-150$ & 420.7 & 7.76 & 5.34 & 34.1 & 46.80 & 15.93 & 544.0 & 23.13 & 28.3 & 1167 & 105 & 8.55 & 58.9 & 741 \\
\hline $49 X-4,140-150$ & 458.7 & 7.74 & 4.61 & 34.5 & 47.56 & 15.01 & 550.0 & 24.93 & 37.7 & 633 & 126 & 8.64 & 52.0 & 967 \\
\hline
\end{tabular}

contain about $200 \mathrm{ppm}$ fluoride, which is incorporated from seawater during rapid growth of calcitic tests (Froelich et al., 1983). Upon near-equilibrium dissolution and reprecipitation, inorganic calcite excludes $\mathrm{F}$, partitioning it into the interstitial solution, similar to Sr. Thus, F gradients are sensitive indicators of contemporaneous carbonate recrystallization reactions in calcareous sediments. However, the $\mathrm{F}$ profile at Site 704 also requires that $\mathrm{F}$ be consumed by some unknown sedimentary reaction at $550 \mathrm{mbsf}$. The inverse behavior of $\mathrm{F}$ and $\mathrm{Li}$ at Site 704 suggests that these reactions may involve both constituents (Fig. 3D). Similar F consumption reactions may be occurring in other sites, where the shapes of the F profiles suggest uptake reactions in the sediment column. Whether this is an artifact of the pore-water extraction process (Froelich et al., 1983), or perhaps disseminated precipitation of trace carbonatefluorapatite (francolite), is unknown.

\section{CONCLUSIONS}

Pore-water profiles in the Leg 114 holes can be used to infer chemical reactions occurring in the sediment column and in basement below the recovered section. Characteristic calcium and magnesium gradients confirm that basement under the East Georgia Basin and Islas Orcadas Rise (and, by analogy, the conjugate Meteor Rise) are basaltic in composition. These gradients on the Meteor Rise and the western flank of the Mid-Atlantic Ridge are obscured by sediment-hosted silicic volcanic ash alteration reactions. Carbonate dissolution and recrystallization reactions are inferred from fluoride and strontium profiles to dominate the biogenic oozes atop the Meteor Rise, where strontium concentrations approach equilibrium with celestite within $200 \mathrm{mbsf}$. Lithium and fluoride are involved in both sedimentary production and consumption reactions linked to carbonate diagenesis and other as yet unidentified processes. Salinity (chloride) gradients in the upper $200 \mathrm{~m}$ of these sites suggest that while sites at intermediate water depths on the Islas Orcadas and Meteor rises and in the East Georgia Basin underwent higher bottom-water salinities during the late Pleistocene, the deepest site in the main channel of AABW flow northward from the Southern Ocean into the Atlantic has experienced no salinity changes in the last few million years. 
Table 3 (continued).

\begin{tabular}{|c|c|c|c|c|c|c|c|c|c|c|c|c|c|c|}
\hline $\begin{array}{l}\text { Core, section, } \\
\text { interval }(\mathrm{cm})\end{array}$ & $\begin{array}{l}\text { Depth } \\
\text { (mbsf) }\end{array}$ & $\mathrm{pH}$ & $\begin{array}{l}\text { Alkalinity } \\
(\mathrm{mM})\end{array}$ & $\begin{array}{c}\text { Salinity } \\
(\% / \%)\end{array}$ & $\underset{(m M)}{M g}$ & $\underset{(\mathrm{mM})}{\mathrm{Ca}}$ & $\underset{(\mathrm{mM})}{\mathrm{Cl}}$ & $\begin{array}{c}\mathrm{SO}_{4} \\
(\mathrm{mM})\end{array}$ & $\underset{(\mu \mathrm{M})}{\mathbf{F}}$ & $\underset{(\mu \mathrm{M})}{\mathrm{Si}}$ & $\begin{array}{c}\mathrm{Sr} \\
(\mu \mathrm{M})\end{array}$ & $\underset{(\mathrm{mM})}{\mathrm{K}}$ & $\underset{(\mu \mathrm{M})}{\mathrm{Li}}$ & $\begin{array}{c}\mathrm{Ba} \\
(\mathrm{nM})\end{array}$ \\
\hline \multicolumn{15}{|l|}{$114-702 \mathrm{~A}=$} \\
\hline $1 \mathrm{H}-2,145-150$ & 2.9 & 7.70 & 2.92 & 34.2 & 53.29 & 10.88 & 552.0 & 29.14 & 67.0 & 793 & 111 & 9.52 & 25.1 & 896 \\
\hline $3 \mathrm{H}-5,145-150$ & 21.5 & 7.65 & 2.93 & 35.0 & 53.40 & 11.57 & 561.0 & 28.28 & 65.0 & 819 & 125 & 9.56 & 28.2 & 398 \\
\hline \multicolumn{15}{|l|}{ 114-702B- } \\
\hline $1 \mathrm{H}-3,145-150$ & 4.4 & 7.57 & 3.00 & 34.7 & 53.59 & 10.90 & 556.0 & 28.63 & 67.5 & 802 & 99 & 10.02 & 25.7 & 463 \\
\hline $3 \mathrm{H}-5,145-150$ & 23.2 & 7.58 & 2.96 & 34.5 & 53.15 & 11.66 & 564.0 & 27.79 & 70.3 & 762 & 137 & 10.22 & 25.1 & 414 \\
\hline $6 \mathrm{X}-1,145-150$ & 45.7 & 7.62 & 3.02 & 34.8 & 52.01 & 13.12 & 563.0 & 27.30 & 68.1 & 787 & 176 & 9.30 & 25.7 & 351 \\
\hline $9 X-4,145-150$ & 78.7 & 7.54 & 2.85 & 34.4 & 50.91 & 14.61 & 560.0 & 27.10 & 71.7 & 749 & 222 & 9.08 & 25.7 & 465 \\
\hline $12 X-5,145-150$ & 108.7 & 7.61 & 2.92 & 34.5 & 48.57 & 16.95 & 559.0 & 26.38 & 68.9 & 787 & 332 & 10.00 & 28.8 & 596 \\
\hline $15 X-5,145-150$ & 137.2 & 7.57 & 2.74 & 34.6 & 47.30 & 18.94 & 564.0 & 25.91 & 70.3 & 730 & 367 & 9.04 & 27.6 & 810 \\
\hline $18 X-5,145-150$ & 165.7 & 7.38 & 2.94 & 34.6 & 45.63 & 21.00 & 566.0 & 25.36 & 76.7 & 798 & 433 & 8.29 & 26.3 & 823 \\
\hline $21 X-2,145-150$ & 189.7 & 7.38 & 2.82 & 34.9 & 45.13 & 22.23 & 564.0 & 25.46 & 81.7 & 560 & 468 & 8.11 & 26.3 & 1033 \\
\hline $24 X-2,145-150$ & 218.2 & 7.47 & 2.68 & 35.0 & 43.34 & 24.42 & 564.0 & 25.61 & 92.8 & 500 & 540 & 7.85 & 26.9 & 675 \\
\hline $30 X-1,145-150$ & 273.7 & 7.42 & 2.47 & 35.2 & 41.15 & 28.68 & 565.0 & 25.15 & 99.7 & 619 & 701 & 8.03 & & 1740 \\
\hline \multicolumn{15}{|l|}{$114-704 \mathrm{~A}-$} \\
\hline $1 \mathrm{H}-4,145-150$ & 5.9 & 7.75 & 3.14 & 34.5 & 54.82 & 10.63 & 567.0 & 28.42 & 70.2 & 840 & 104 & 9.65 & 25.1 & 384 \\
\hline $3 \mathrm{H}-5,145-150$ & 24.1 & 7.70 & 3.46 & 34.9 & 56.15 & 11.38 & 582.0 & 30.02 & 72.2 & 1009 & 124 & 10.44 & 22.6 & 283 \\
\hline $6 \mathrm{H}-3,145-150$ & 49.6 & 7.64 & 3.90 & 35.2 & 55.95 & 11.58 & 583.0 & 29.94 & 62.8 & & 131 & 10.18 & 19.4 & 294 \\
\hline $9 \mathrm{H}-4,145-150$ & 79.6 & 7.66 & 4.05 & 34.9 & 55.19 & 11.46 & 582.0 & 29.31 & 64.1 & & 155 & 9.69 & 16.3 & 257 \\
\hline $12 \mathrm{H}-5,145-150$ & 109.6 & 7.59 & 3.99 & 35.0 & 52.90 & 11.35 & 576.0 & 28.05 & 68.3 & 963 & 266 & 10.13 & 13.2 & 714 \\
\hline $15 \mathrm{H}-5,145-150$ & 138.1 & 7.57 & 4.30 & 34.8 & 49.66 & 12.11 & 573.0 & 26.80 & 78.2 & 1096 & 507 & 10.31 & 10.0 & 376 \\
\hline $18 X-4,145-150$ & 165.1 & 7.41 & 4.37 & 34.8 & 45.72 & 13.73 & 569.0 & 24.95 & 98.1 & 1080 & 705 & 9.78 & 8.8 & 632 \\
\hline $21 X-3,145-150$ & 192.1 & 7.49 & 4.20 & 34.5 & 41.30 & 15.11 & 567.0 & 23.12 & 112.7 & 1037 & 913 & 9.39 & 9.4 & 347 \\
\hline $25 X-4,145-150$ & 231.6 & 7.58 & 3.97 & 34.4 & 36.43 & 16.94 & 566.0 & 21.19 & 127.5 & 1092 & 1087 & 9.74 & 10.0 & 344 \\
\hline \multicolumn{15}{|l|}{ 114-704B- } \\
\hline $27 X-5,145-150$ & 249.6 & 7.57 & 4.16 & 34.4 & 35.68 & 17.46 & 569.0 & 20.55 & 137.6 & 1073 & 1076 & 8.73 & 9.4 & 251 \\
\hline $30 X-2,145-150$ & 273.6 & 7.54 & 4.23 & 34.4 & 33.20 & 18.98 & 569.0 & 19.21 & 158.1 & 1064 & 1151 & 8.33 & 8.8 & 475 \\
\hline $33 X-4,145-150$ & 305.1 & 7.48 & 4.70 & 34.1 & 29.93 & 20.26 & 563.0 & 18.57 & 179.6 & 1154 & 1132 & 8.68 & 8.1 & 407 \\
\hline $36 X-2,145-150$ & 330.6 & 7.41 & 4.38 & 34.0 & 28.77 & 21.11 & 575.0 & 18.35 & 182.5 & 1189 & 1132 & 8.77 & 8.8 & 437 \\
\hline $39 X-5,145-150$ & 363.6 & 7.41 & 4.34 & 34.0 & 27.27 & 21.97 & 565.0 & 17.25 & 178.9 & 1217 & 1219 & 8.51 & 11.3 & 492 \\
\hline $42 X-5,97-107$ & 391.7 & 7.29 & 4.53 & 34.0 & 25.68 & 22.76 & 565.0 & 17.31 & 161.9 & 1249 & 1271 & 8.47 & 14.4 & 464 \\
\hline $46 \times-4,140-150$ & 428.6 & 7.36 & 3.37 & 34.0 & 25.06 & 22.59 & 566.0 & 17.19 & 131.1 & 1164 & 1166 & 7.98 & 18.8 & 748 \\
\hline $48 X-2,140-150$ & 444.6 & 7.35 & 3.23 & 34.0 & 24.26 & 23.31 & 566.0 & 16.35 & 123.0 & 1117 & 1273 & 7.72 & 23.2 & 910 \\
\hline $52 X-4,140-150$ & 478.1 & 7.36 & 3.90 & 34.1 & 22.84 & 24.25 & 567.0 & 15.71 & 113.6 & 1260 & 1302 & 7.90 & 21.9 & 508 \\
\hline $54 X-5,140-150$ & 498.6 & 7.41 & 3.43 & 34.0 & 23.37 & 24.02 & 566.0 & 16.66 & 108.3 & 1216 & 1280 & 7.50 & 23.2 & 474 \\
\hline $58 X-5,140-150$ & 536.6 & 7.46 & 3.35 & 34.1 & 23.28 & 24.33 & 563.0 & 16.63 & 98.9 & 1133 & 1301 & 7.63 & 26.3 & \\
\hline $60 X-5,140-150$ & 555.6 & 7.44 & 3.50 & 33.9 & 19.67 & 25.47 & 571.0 & 15.51 & 96.9 & 1139 & 1361 & 7.41 & 22.6 & 723 \\
\hline $63 \times-4,140-150$ & 582.6 & 7.36 & 2.54 & 34.0 & 20.45 & 25.81 & 571.0 & 15.15 & 110.5 & 1134 & 1463 & 6.71 & 28.8 & 1178 \\
\hline $70 X-1,140-150$ & 644.6 & 7.42 & 2.89 & 33.9 & 15.91 & 27.13 & 566.0 & 13.48 & 124.5 & 1240 & 1535 & 7.37 & & \\
\hline $72 X-2,140-150$ & 665.1 & 7.48 & 1.91 & 33.6 & 15.26 & 26.83 & 564.0 & 13.70 & 146.6 & 1247 & 1463 & 7.19 & & 1341 \\
\hline a Seawater & & $\sim 7.76$ & 2.38 & (35.0) & 54.05 & 10.68 & 558.6 & 28.90 & 69.3 & $\sim 100$ & $\sim 90$ & 10.45 & $\sim 26.0$ & $\sim 100$ \\
\hline
\end{tabular}

Note: Values in parentheses are questionable and are not plotted in Figures 1-4.

${ }^{\text {a }}$ Seawater concentrations are given for 35 per mil salinity, and the concentrations for nonconservative elements are for bottom water in the South Atlantic. Salinities were not measured at the drill sites, but typical deep and bottom water salinities in the South Atlantic are $34.6 \%$

\section{ACKNOWLEDGMENTS}

We thank the co-chief scientists (Paul Ciesielski and Yngve Kristoffersen) for the opportunity for one of us (PNF) to participate on Leg 114. J. Bishop (Lamont) assisted with the barium analyses. Funding was provided by grants from the National Science Foundation (OCE-87-11588) and JOI/USSACS (TAMRF-20116).

\section{REFERENCES}

Baker, P. A., 1986. Pore-water chemistry of carbonate-rich sediments, Lord Howe Rise, southwest Pacific Ocean. In Kennett, J. P., von der Borch, C. C., et al., Init. Repts. DSDP, 90: Washington (U.S. Govt. Printing Office), 1249-1256.

Baker, P. A., and Bloomer, S. H., 1988. The origin of celestite in deep-sea carbonate sediments. Geochim. Cosmochim. Acta, 52:335-339.

Bishop, J., 1990. Determination of barium in seawater using vanadium/silicon modifier and direct-injection graphite furnace atomic absorption spectrometry. Anal. Chem., 62:553-557.

Froelich, P. N., Kim, K. K., Jahnke, R. J., Burnett, W. R., and Deakin, M., 1983. Pore water fluoride in Peru continental margin sediments: uptake from seawater. Geochim. Cosmochim. Acta, 47:1605-1612.

Froelich, P. N., Mortlock, R. A., and Shemesh, A., 1989. Inorganic germanium and silica in the Indian Ocean: biological fractionation during $(\mathrm{Ge} / \mathrm{Si})_{\text {opal }}$ formation. Global Biogeochem. Cycl., 3:79-88.

Gieskes, J. M., 1974. Interstitial water studies, Leg 25. In Simpson, E.S.W., Schlich, R., et al., Init. Repts. DSDP, 25: Washington (U.S. Govt. Printing Office), 361-394.

1981. Deep-sea drilling interstitial water studies: implications for chemical alteration of the oceanic crust, Layers I and II. In Warmer, T. E., Douglas, R. C., and Winterer, E. L. (Eds.), The Deep Sea Drilling Project: A Decade of Progress. Spec. Publ. Soc. Econ. Paleontol. Mineral., 32:149-167.

1983. The chemistry of interstitial waters of deep-sea sediments: interpretation of Deep-Sea Drilling data. In Riley, J. P., and Chester, R. (Eds.), Chemical Oceanography (vol. 8): London (Academic Press), 223-269.

Gieskes, J. M., Johnston, K., and Boehm, M., 1984. Interstitial water studies, Leg 74. In Moore, T. C., Rabinowitz, P. D., et al., Init. Repts, DSDP, 74: Washington (U.S. Govt. Printing Office), 701-711.

Gieskes, J. M., and Lawrence, J. R., 1981. Alteration of volcanic matter in deep-sea sediments: evidence from chemical composi- 


\section{P. N. FROELICH ET AL.}

tion of interstitial waters from deep sea drilling cores. Geochim. Cosmochim. Acta, 45:1687-1703.

Gieskes, J. M., and Peretsman, G., 1985. Water Chemistry Procedures Aboard JOIDES Resolution-Some Comments. ODP Tech. Note, 5.

Manheim, F. T., and Sayles, F. L., 1974. Composition and origin of interstitial waters of marine sediments based on deep sea drill cores. In Goldberg, E. D. (Ed.), The Sea (vol. 5): New York (Wiley), 527-568.

McDuff, R. E., 1981. Major cation gradients in DSDP interstitial waters: the role of diffusive exchange between seawater and upper oceanic crust. Geochim. Cosmochim. Acta, 45:1705-1713.

1985. The chemistry of interstitial waters, Deep Sea Drilling Project Leg 86. In Heath, G. R., Burckle, L. H., et al., Init. Repts. DSDP, 86: Washington (U.S. Govt. Printing Office), 675-687.

Mortlock, R. A., and Froelich, P. N., 1989. A simple method for the rapid determination of biogenic opal in pelagic marine sediments. Deep-Sea Res., Part A, 36:1415-1426.
Shemesh, A., Mortlock, R. A., and Froelich, P. N., 1989. Late Cenozoic $\mathrm{Ge} / \mathrm{Si}$ record of marine biogenic opal: implications for variations of riverine fluxes to the ocean. Paleoceanography, $4: 221-234$.

Shipboard Scientific Party, 1988. Explanatory Notes. In Ciesielski, P. F., Kristoffersen, Y., et al., Proc. ODP, Init. Repts., 114; College Station, TX (Ocean Drilling Program), 3-22.

von Damm, K. L., 1983. Chemistry of submarine hydrothermal solutions at $21^{\circ}$ North, East Pacific Rise and Guaymas Basin, Gulf of California [Ph.D. dissert.]. Woods Hole Oceanographic Inst./ MIT, Woods Hole, MA.

Date of initial receipt: 4 April 1989

Date of acceptance: 12 November 1989

Ms 114B-153 
SITE 699
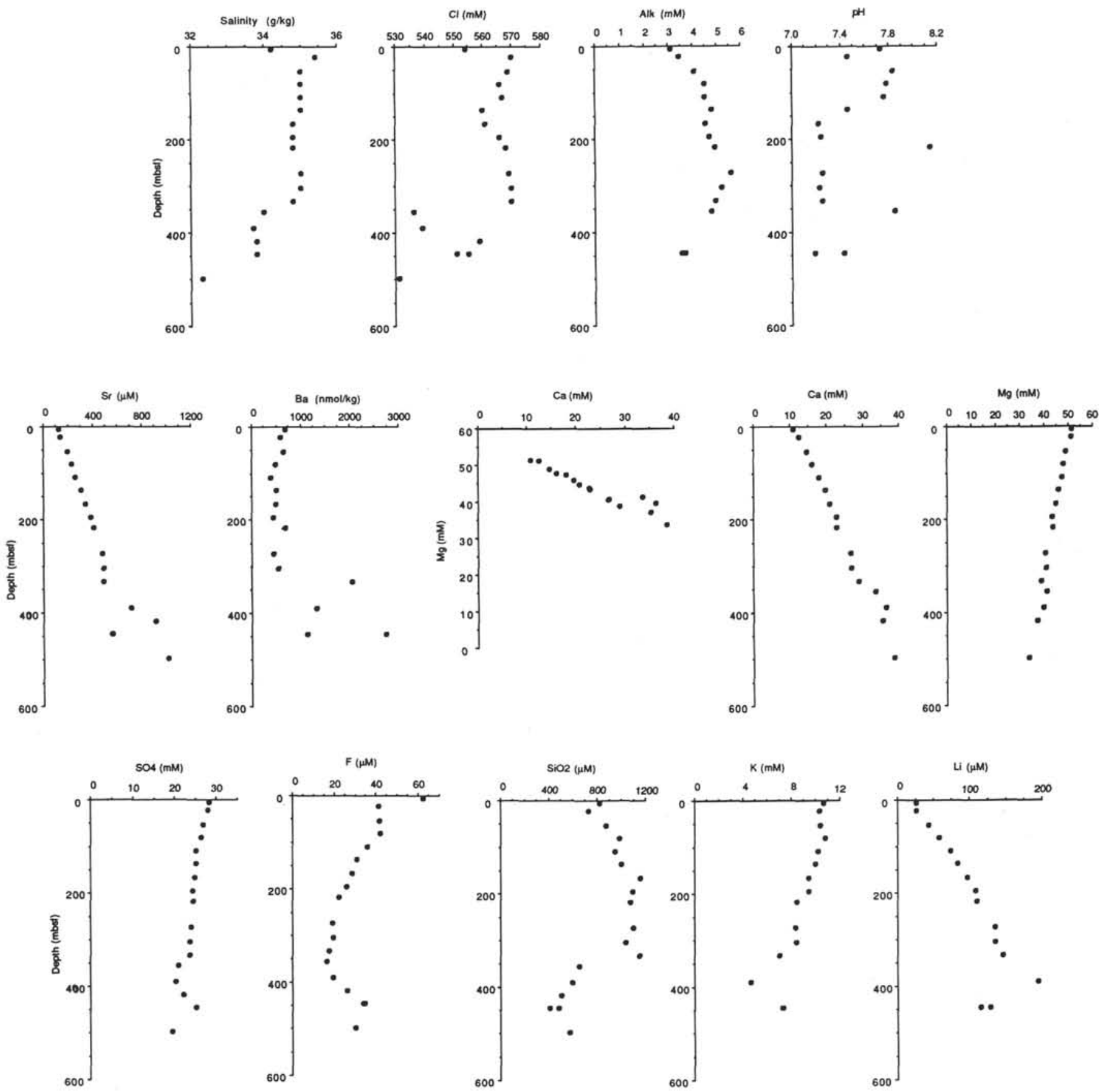

Figure 1. Vertical profiles of pore-water constituents vs. depth at Sites 699-702 and 704. The central plot is pore-water calcium vs. magnesium. 
P. N. FROELICH ET AL.

SITE 700


Figure 1 (continued), 
SITE 701
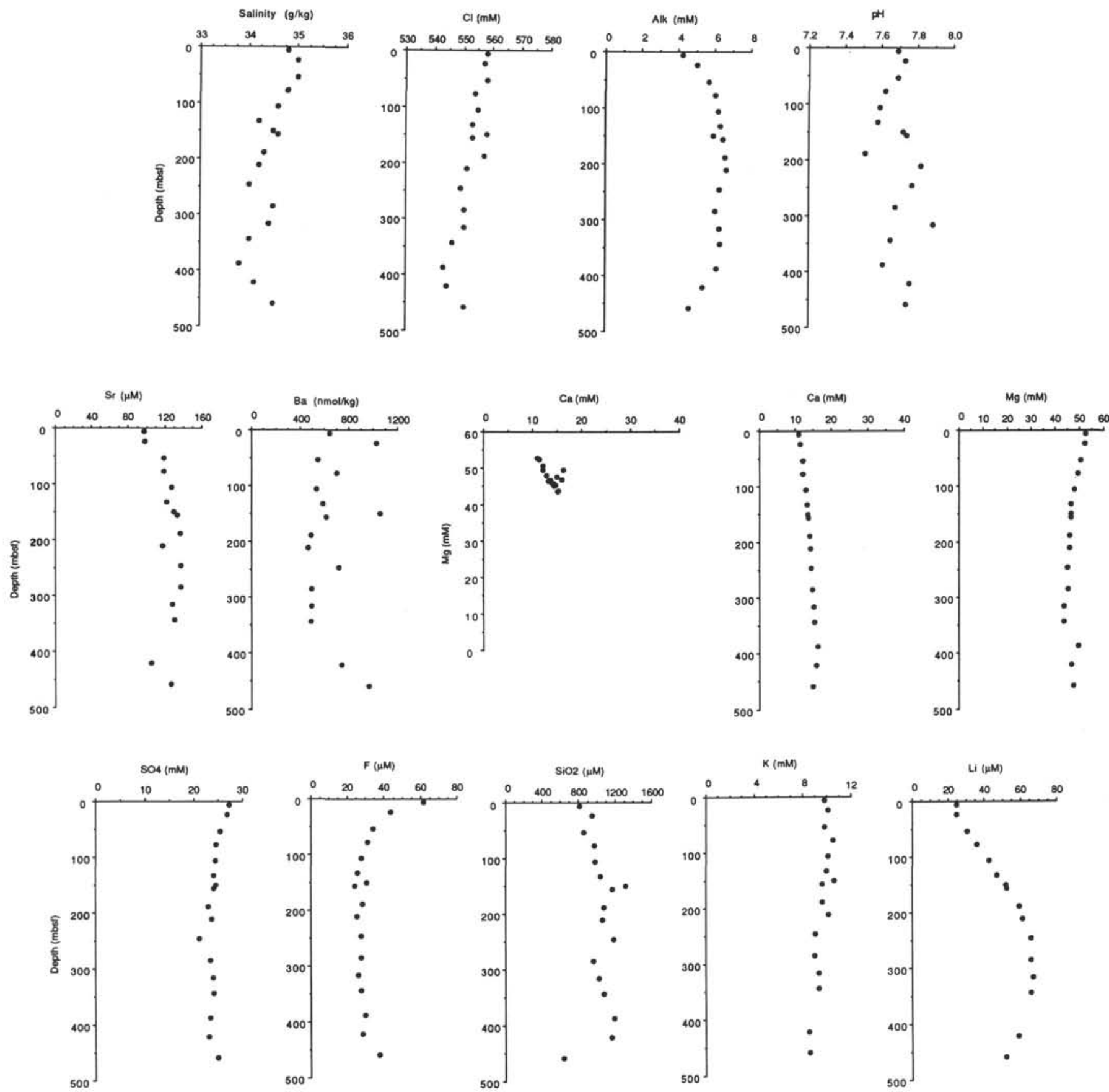

Figure 1 (continued). 


\section{SITE 702}
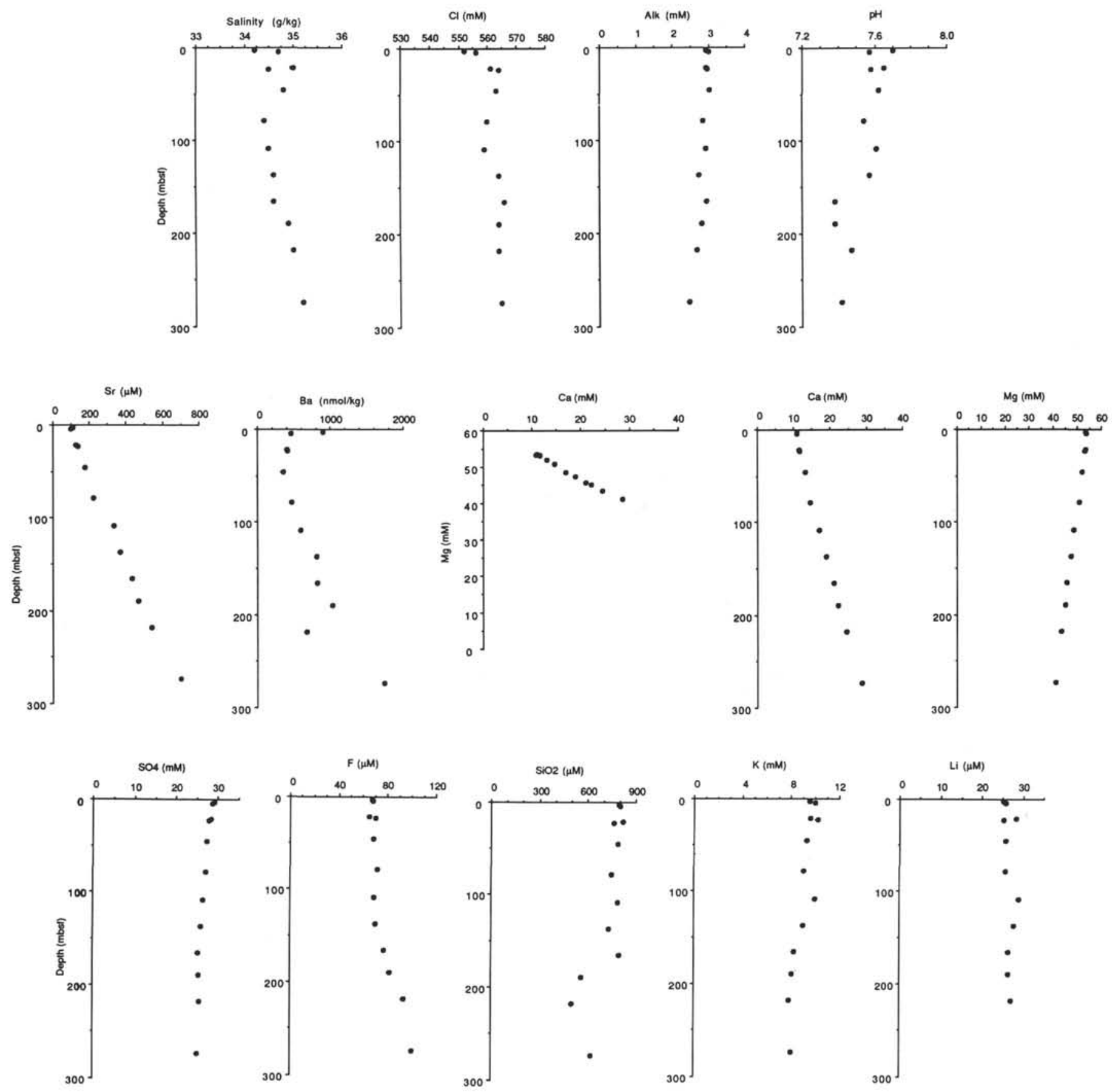

Figure 1 (continued). 


\section{SITE 704}
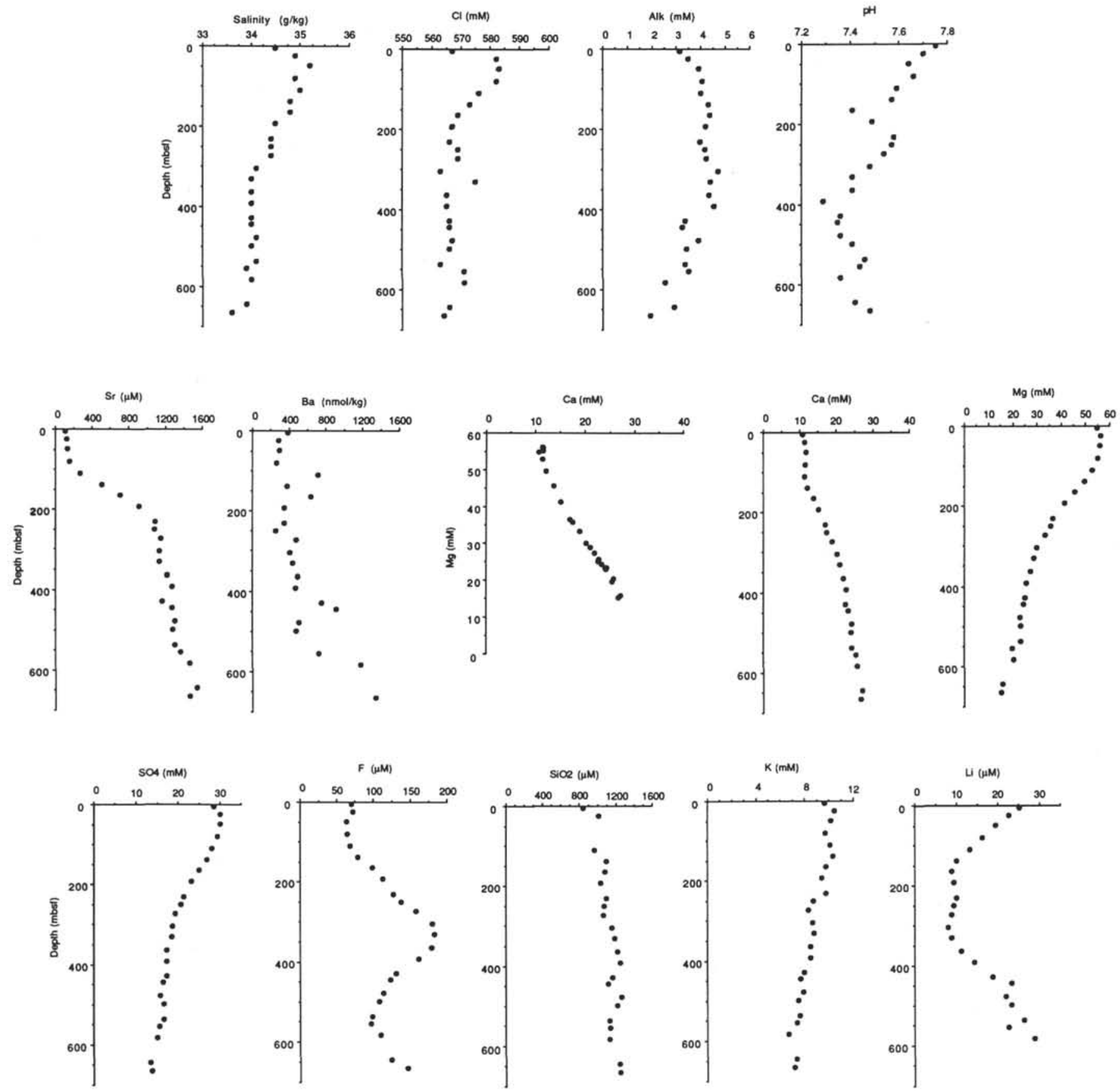

Figure 1 (continued). 


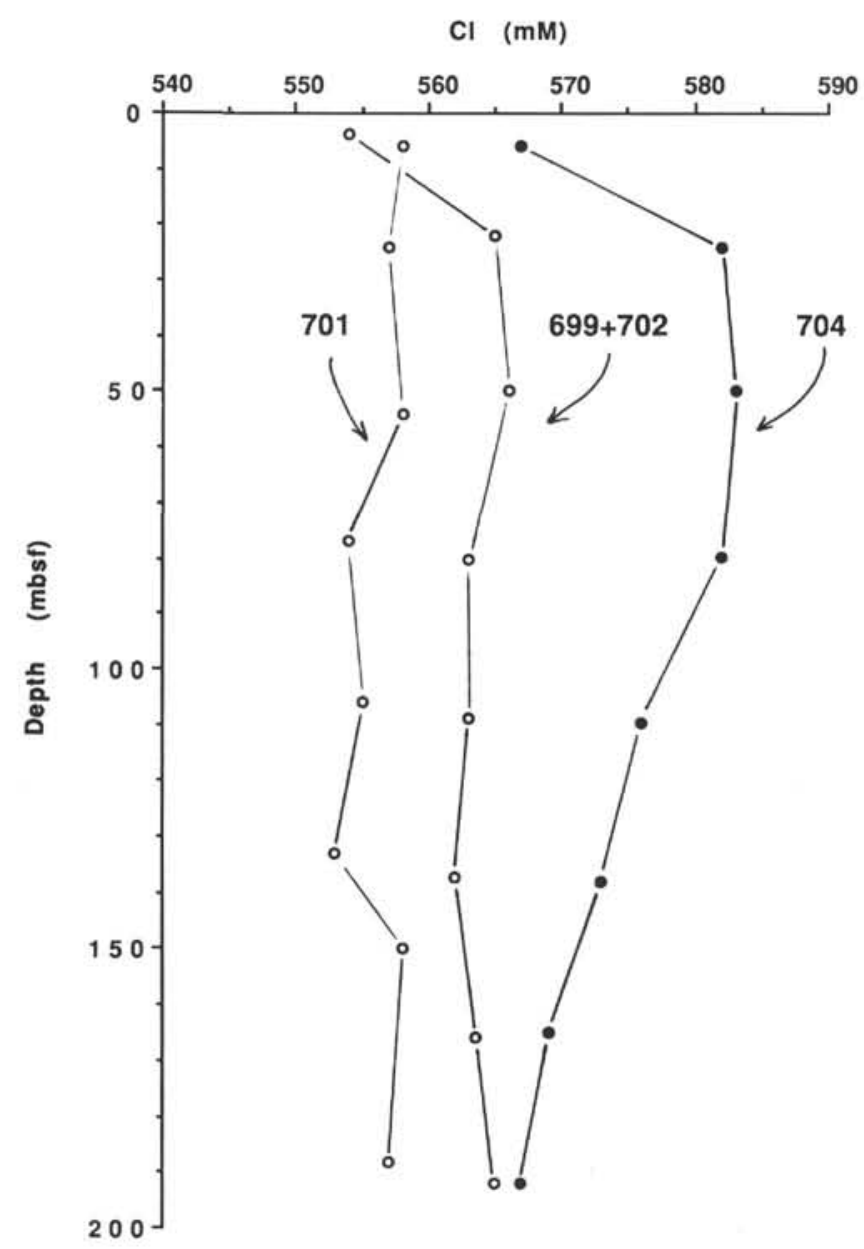

Figure 2. Pore-water chloride concentrations vs. depth. The data from Sites 699 and 702 were averaged for this plot. Site 701 is presently under the influence of AABW, while Sites 699, 702, and 704 are under CPDW and NADW. Except for Site 701, these profiles reflect the diffusion downward into the sediment column of Pleistocene variations in bottom-water chloride concentrations related both to wholeocean salinity changes (glacial to interglacial continental ice volume changes) and to local water-mass variations (NADW).
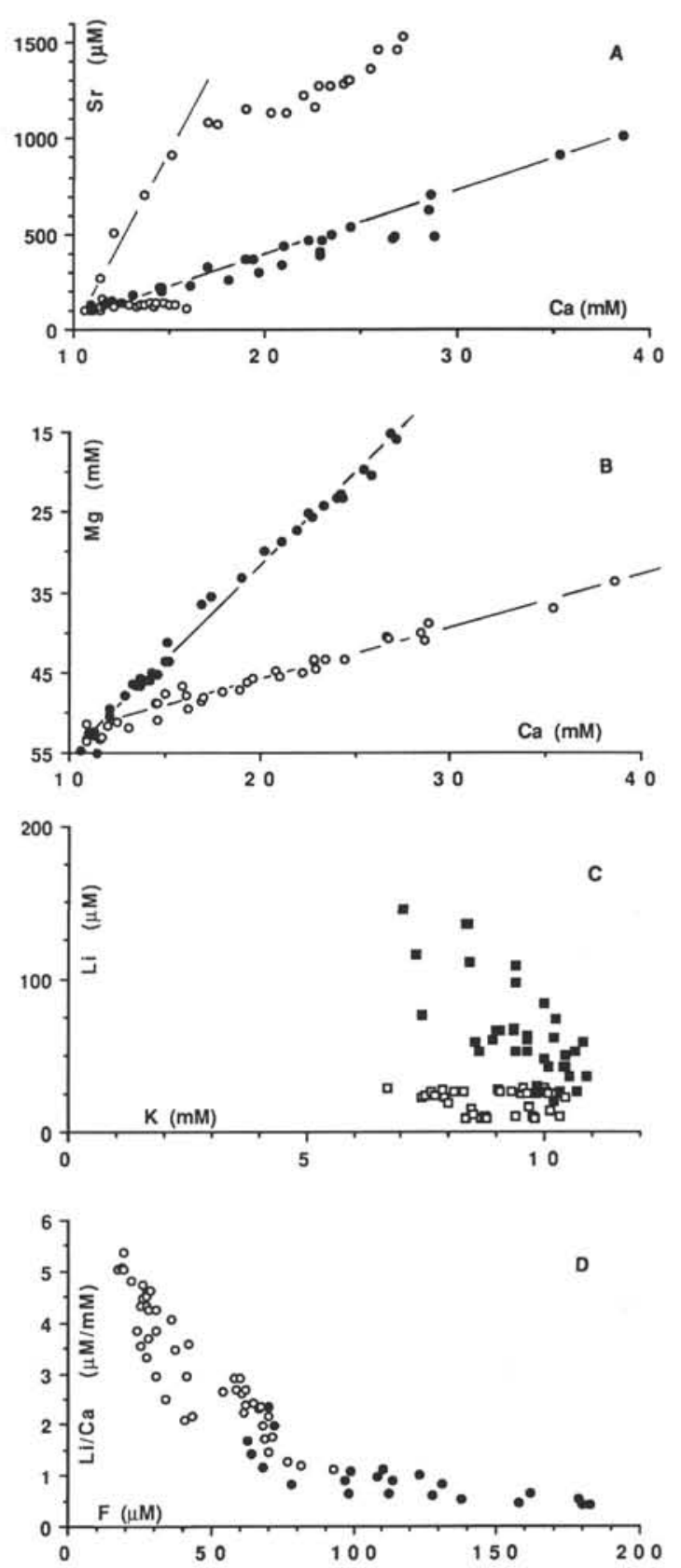

Figure 3. A. Pore-water strontium vs. calcium for all sites. Symbols for Sites 699, 700, and 702 are solid circles; Sites 704 (upper points) and 701 (lower points) are open circles. The straight line through the solid symbols has a slope $(\mathrm{Sr} / \mathrm{Ca})$ of $36 \times 10^{-3}$. The straight line through the open symbols has a slope of $220 \times 10^{-3}$. B. Pore-water magnesium vs. calcium for all sites. Symbols for Sites 699,700 , and 702 are open circles. The line through these points has a $\delta \mathrm{Mg} / \delta \mathrm{Ca}$ ratio of -0.5 , indicative of diffusive exchange with basement via low-temperature basalt-seawater reactions and conservative behavior in the sediment column (absence of ash and dolomitization). Symbols for Sites 701 and 704 are solid circles. The line through these points has a $\delta \mathrm{Mg} / \delta \mathrm{Ca}$ slope of -2.0 , indicative of diagenetic alteration of silicic volcanic ash contained in the sediment column at these sites. $\mathbf{C}$. Pore-water lithium vs. potassium for all sites. Symbols for Sites 699, 700 , and 701 are solid squares. Open squares are Sites 702 and 704. D. Pore-water $\mathrm{Li} / \mathrm{Ca}$ ratios vs. F for all sites. Symbols for Site 704 are solid circles; all other sites are open circles. 

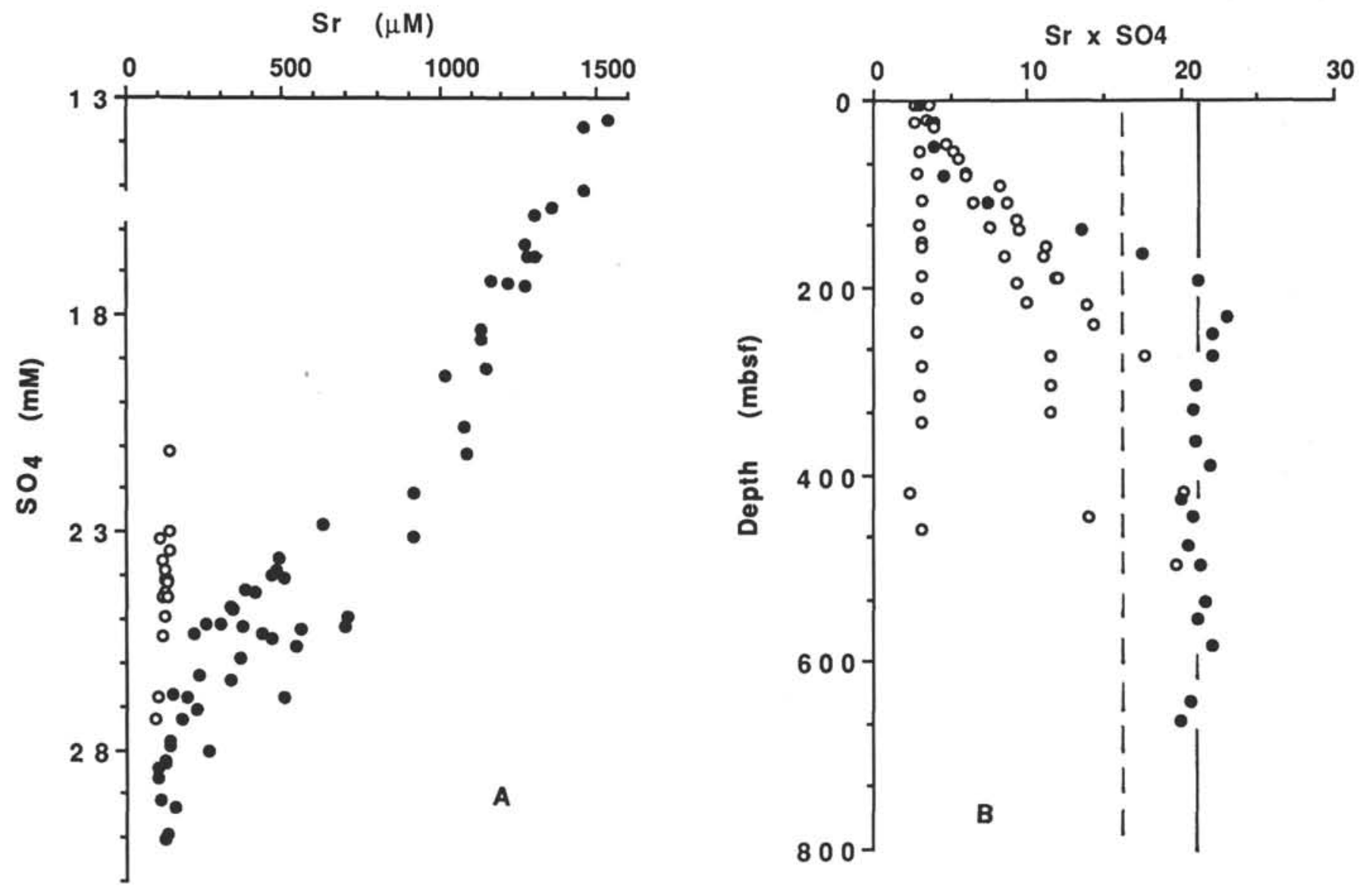

Figure 4. A. Pore-water strontium vs. sulfate concentrations. Symbols for Sites 699, 700, 702, and 704 are solid circles; the symbol for Site 701 is an open circle. B. The ICP for celestite $\left(\mathrm{Sr} \times \mathrm{SO}_{4}\right)$ plotted vs. depth for all sites. Symbols for Sites $699-702$ are open circles; the symbol for Site 704 is a solid circle. The vertical solid line represents an ICP $=21 \times 10^{-6}$, suggested as the solubility product for equilibrium with celestite at Site 704 (water depth $=2500 \mathrm{~m}$ ). The vertical dashed line is for an ICP $=16 \times 10^{-6}$ from sites on the Lord Howe Rise (water depth $=1000$ m; Baker, 1986). 